УДК 7.03; 7:001.12

Ольга Николаевна Филиппова, заведующая архивом, Политехнический музей, Москва, Россия, e-mail: iscusstvo0891@mail.ru, ORCID: 0000-0002-8933-1214

\title{
ТВОРЧЕСТВО НАТАЛЬИ СЕВЕРЦОВОЙ
}

Аннотация. Наталия Алексеевна СеверцоваГабричевская (1901-1970 гг.) была яркой и незаурядной личностью. Природный темперамент, артистичность, красота привлекали к ней ученых и художников. И если в московской жизни профессиональная занятость и научные штудии круга друзей ее мужа определяли и ритм, и стиль общения, то в Коктебеле, куда ехали жить свободно, играть, отдыхать, складывалась атмосфера, в которой расцветал ее талант хозяйки дома, душевного круга, дар художницы. Н. А. Северцова создавала то, что специалисты определяют как наивное искусство. Можно было бы сказать, что ее творчество сформировалось вопреки тем вкусам и художественным идеалам, которые были присущи ее друзьям и наставникам из ближайшего окружения. Это был пример наивного видения, остающегося целым в элитарной среде. Однако, Н. А. Северцова была человеком своего круга - подлинным интеллигентом, с присущим независимо мыслящим людям взглядом на мир, острым, часто ироничным, всегда нестандартным. С течением времени - десятков лет, прошедших с того периода, когда вокруг стола в коктебельском доме Габричевских собиралась веселая дружеская компания, - становится ясно, что угнетающему давлению советской действительности противостояли люди, связанные дружескими и профессиональными отношениями, общими интересами и увлечениями. В искусстве Н. А. Северцовой воплотился тот 
образ жизни и стиль самовыражения, который был присущ кругу людей, собиравшихся в доме Северцовых-Габричевских, наследовавший бытовой культуре отцов и дедов, хранивший их привычки, манеры, способы суждения столь же бережно, как произведения живописи и графики, достававшиеся в наследство. Эти традиции продолжает хранить племянница и воспитанница Н.А. Северцовой - О.С. Северцева (р. 1931). Она сохранила не только все художественное наследие Н. А. Северцовой, но и архивы всех ученых, принадлежавших этой исключительной семье.

Ключевые слова: Творчество Натальи Северцовой, Коктебель, искусство, музыка, театральная студия, актриса, звукоподражатель, живопись, натюрморты, портреты

Введение. Человек прожил жизнь, и имя его потом связывается с тем, что он после себя оставил. Так, было и с именем Натальи Алексеевны Северцовой-Габричевской, широко известным многим, среди кого были музыканты, артисты, художники, искусствоведы, ученые и просто любители прекрасного. Она оставила после себя самобытное, яркое, неповторимое искусство, несущее людям радость. Встреча с работами Н. А. Северцовой сегодня - это знакомство с галереей образов, созданных большим талантом и творческим темпераментом художника, который по-своему, очень остро, видел и понимал мир.

Постановка проблемы. Творчество Натальи Северцовой - это малоизученное, но удивительно радостное и сложное явление русского искусства ХХ в. Оно приходится на 1950-1960-е гг., - время, когда были созданы многие из ее произведений. Эти же годы хорошо известны современному российскому зрителю по искусству художниковнонконформистов. Корпус ее гавных произведений и будет основным предметом внимания статьи. 


\section{Анализ последних исследований и публикаций.} Творчество Н. А. Северцовой, по словам исследователей, своеобразно, т. к. необычны его истоки. В книге-альбоме Елизаветы Плавинской о Наталье Северцовой, в качестве научного комментария приводятся выдержки из двух статей ее друзей: А. А. Румнева (1899-1965 рр.), актера, просвещенного человека, поддерживающего живые веяния в русском искусстве 1950-1960-х гг., и ученого-энциклопедиста, искусствоведа Р. Б. Климова (1928-2000рр.) [8; 9; 11]. Из воспоминаний А. А. Румнева о живописи Н. А. Северцовой: «Живопись Натальи Северцовой программна. Однако, натура для нее лишь отправная точка еe вымышленных портретов, натюрмортов и многофигурных жанровых композиций. Чаще всего эта страна вымысла связана с любимым ей Коктебелем, с его природой и людьми, наблюдаемыми ею издавна и по сегодняшний день. И именно тогда зоркость глаза, юмор и способность передать в портретах целые биографии проявляется у Н. А. Северцовой с особой остротой» [3, с. 14].

Таким образом, особой главой в жизни и творчестве Н. А. Северцовой является Коктебель - бывшая деревня на восточном берегу Крыма, где вокруг дома М. А. Волошина (1877-1932 гг.), а потом и вокруг дома Габричевских на протяжении десятилетий продолжал сохраняться круг исключительных людей - заповедник русского искусства и мысли XX в. В книге Е. И. Жаркова: «Страна Коктебель. Культурные очаги. Середина XIX - середина XX веков» автор рассказывает о Н. А. Северцовой, где она родилась, у кого училась, что было присуще ее стихийному творчеству [4]. Между тем, на сегодняшний день нет подробных публикаций, посвященных ее творчеству, комплексного анализа ее работ.

Цель данной публикации - осветить творчество Н. А. Северцовой, которая обладала редким даром впитывать красоту мира, наслаждаться ею и дарить другим. 
Изложение оновного материала. Наталия Алексеевна Северцова родилась в 1901 г. в Москве. Ее дед, Николай Алексеевич Северцов (1827-1885 гг.), был зоологомпутешественником, отец, Алексей Николаевич Северцов (18661936 гг.) - зоологом-морфологом, брат, Сергей Алексеевич зоологом, и племянник, сын брата - тоже зоологом. Четыре поколения зоологов. Н. А. Северцова росла в любви к природе, ко всем животным и насекомым, к ящерицам и змеям; для нее не было страшных и безобразных существ. В 1920 г. она вышла замуж за искусствоведа Александра Георгиевича Габричевского (1891-1968 гг.), брата художника - Евгения Габричевского. Историк и теоретик искусства, литературовед, переводчик, доктор искусствоведения, ученый с мировым именем. Это все об А. Г. Габричевском. В 1915 г. он окончил историкофилологический факультет Московского университета. А в 1918 г. начал педагогическую деятельность (Московский университет, Высший архитектурно-строительный институт, Институт аспирантуры Академии архитектуры СССР в Москве). А. Г. Габричевский - это автор многих работ по истории и теории архитектуры, живописи (главным образом, эпохи Возрождения), музыки и литературы.

Он стоял во главе процесса издания многих классических трудов Л.-Б. Альберти, Дж. Вазари, Виньолы, Витрувия, Палладио и других. А. Г. Габричевскому также принадлежат переводы трудов писателей итальянского Ренессанса и философского сочинения Данте: «Пир» (1968г.) [4, с. 422]. Он был также другом многих талантливых и интеллигентных людей того времени - А. Белого, В. Брюсова, М. Волошина, Г. Нейгауза, Б. Пастернака, С. Рихтера, Р. Фалька, М. Цветаевой и др. 26 мая 1924 г. Н. Северцова-Габричевская вместе с мужем впервые приехала в Коктебель. И с этого времени киммерийский поселок становится для Габричевских непременным местом отдыха и творчества. Они влюбились в эту землю на всю жизнь и постоянно сюда возвращались. 
Исключением были военные годы и время, которое А. Г. Габричевский провел в тюрьмах и ссылках. Н. А. Северцову-Габричевскую всегда интересовали искусство и музыка. Она училась в театральной студии Ю. А. Завадского, была актрисой, пела, работала на радио, как звукоподражатель (в постановке: «Каштанка», «Спор Ивана Ивановича с Иваном Никифоровичем» и др.) $[3$, с. 8]. Благодаря живописному и танцевальному таланту, а также дару звукоподражания Наталии Алексеевны и эрудиции Александра Георгиевича, они зачастую становились инициаторами, как интеллектуальной, так и развлекательной жизни Дома Поэта. Уже после войны Габричевским удалось купить небольшой домик в Коктебеле, который в 1950-х-1960-х гг. стал одним из главных культурных центров поселка. Здесь любили гостить А. А. Румнев, Р. Б. Климов, приезжал к ним и поэт И. А. Бродский. Его портрет Н.А. Северцова напишет в 1969 г. (рис. 1). Серьезно заниматься живописью Н. А. Северцова начала лишь в начале 1950-х гг., в Коктебеле. К ее шедеврам из Коктебельской серии относятся: «Никто никому не грубит. Шалман», «Жених и невеста», «Деревенский оркестр», «Парикмахерская» и более ранние, такие как: «Татарская семья за трапезой», «Влюбленная пара татар» (рис. 2, 3). К лучшим ее работам относятся и некоторые натюрморты, навеянные Коктебелем, такие как: «Капуста и редиска», «Дыня», «Татарский столик с желтой дыней и каперсами» и др. (рис. 4, 5). 


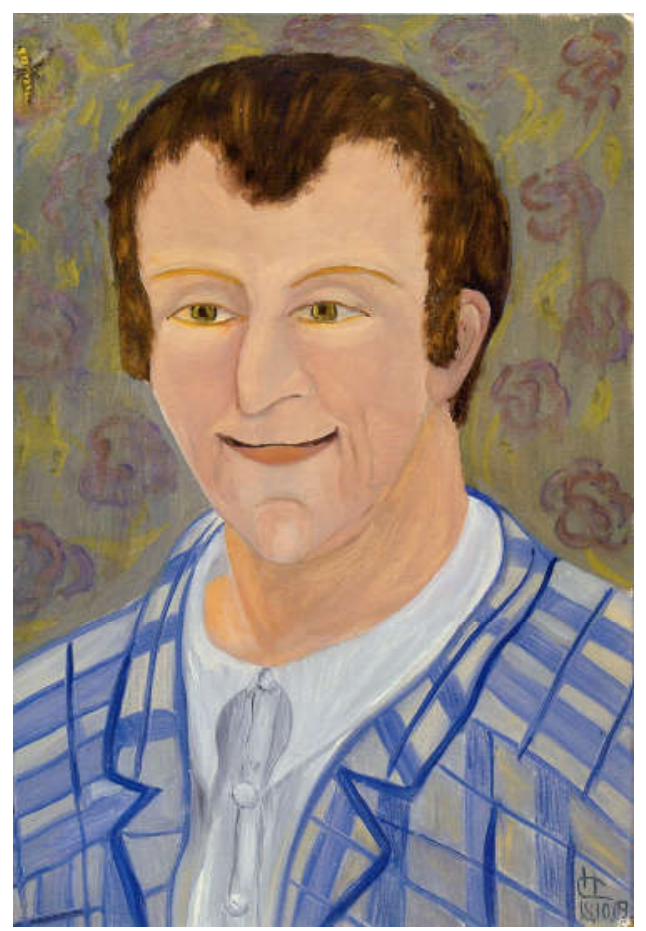

Рис. 1. Севериова Н. А. «Портрет поэта Иосифа Александровича Бродского». 1969 г. Холст на картоне, масло. Частное собрание О. С. Севериевой

Крымская тема отражена Н. А. Северцовой и в цикле портретов, как, например, рбота «Предки», где изображены романтические пираты, рыбаки и рыбачки, некогда населявшие Коктебель. Более шаржированный характер носят типы «Базарного цикла», посвященного Феодосии. Считая, что живопись должна украшать жизнь, Н. А. Северцова вторгается с нею прямо в быт. Отсюда множество предметов обихода, расписанных еe рукой, - подносов, татарских столиков, украшенных коктебельскими растениями и рыбами, оконных 
наличников и дверных створок и среди них великолепные по юмору и красочному богатству створки шкафа с изображением («Фрайера и бандерши» [3, с. 80]).

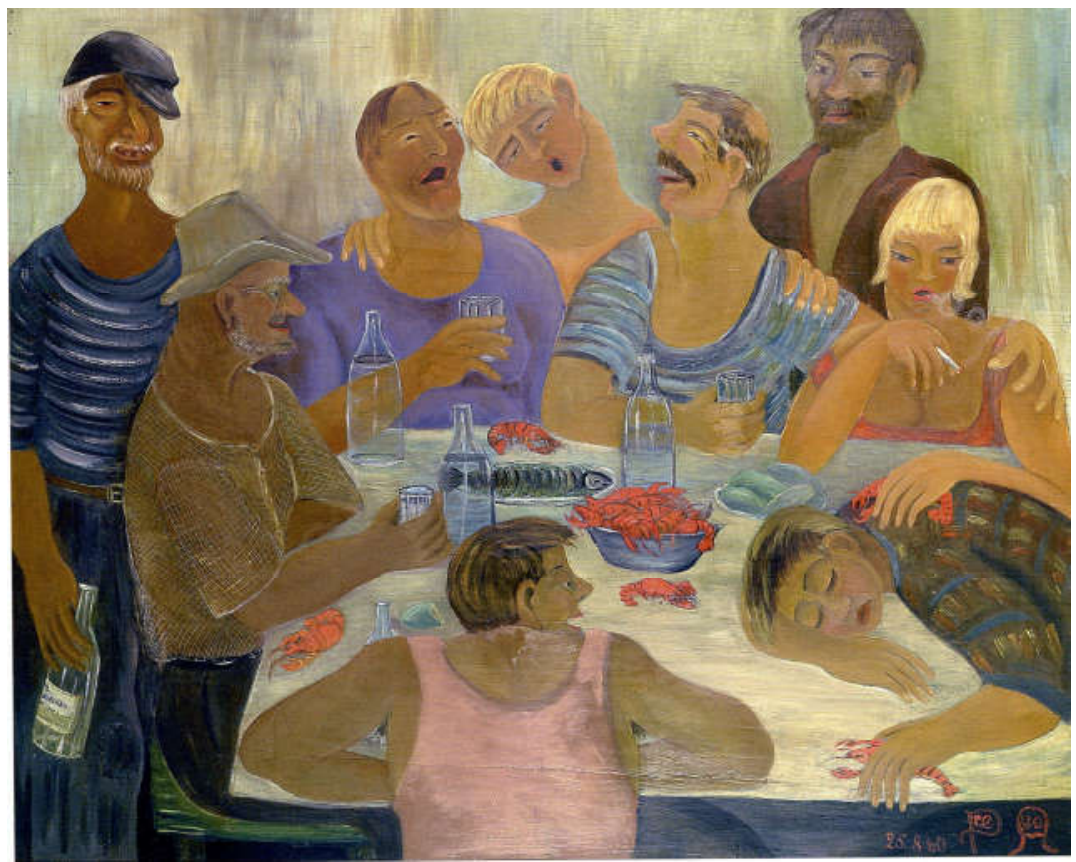

Рис. 2. Севериова Н. А. «Никто никому не грубит. Шалман». 25.08.1960 г. Фанера, масло. Частное собрание

О. С. Севериевой

Из воспоминаний Н. А. Северцовой об этой работе: «... Я стала «своим» художником у сельских жителей. Женщины мне приносили всякую утварь: подносы, металлическую и керамическую посуду, разные крышки и черепки - с просьбой их расписать...» [3, с. 8]. Иногда Н. А. Северцова погружается в воспоминания прошлого, и тогда из-под ее кисти возникают такие своеобразные сюжеты, как «Монахи. Пасха (После 
заутрени в монастыре)», «Санька в санках. Ямщик», «Шарманщик», «Освещение куличей», или цикл «Ложи (I-V)», где изображены театралы, следящие из лож за оперным спектаклем (Илл. 6, 7, 8, 9) [3, с. 38].
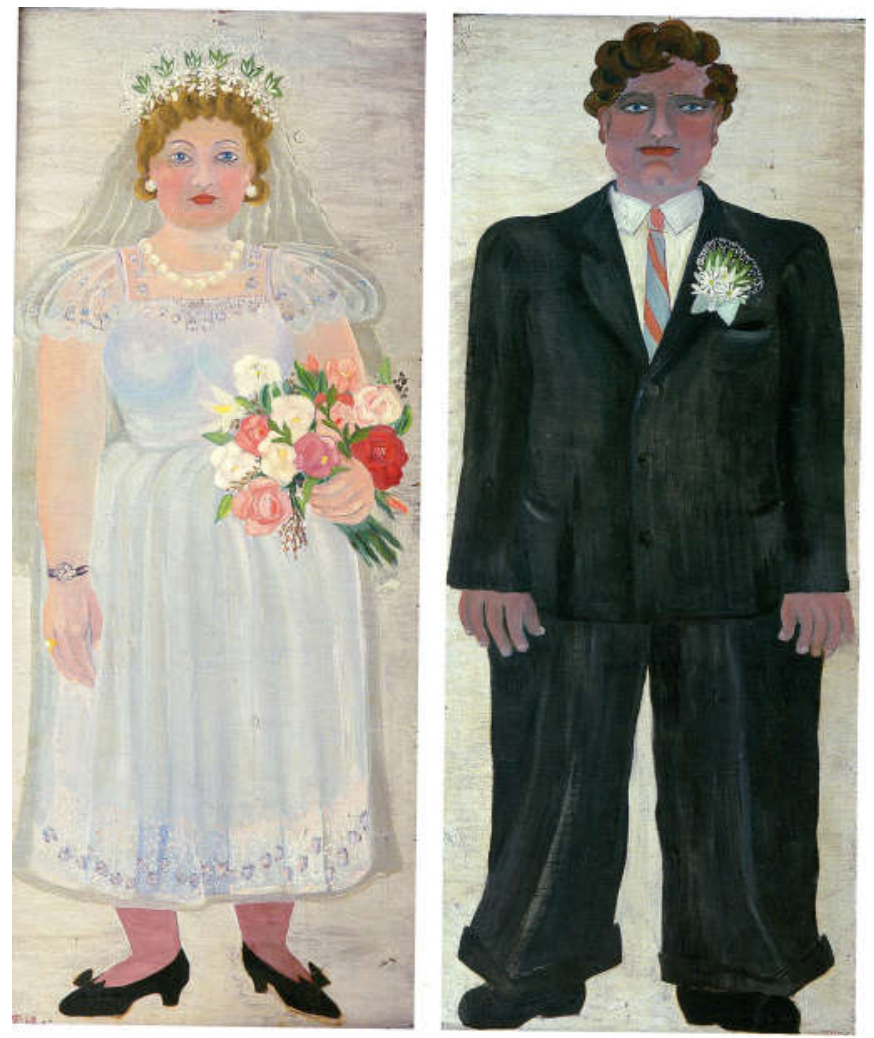

Рис. 3. Севериова Н. А. «Жених и невеста. Диптих». «Жених».

09.07.1962 г. Фанера, масло, серебряная краска; «Невеста». 10.07.1962 2. Фанера, масло, серебряная краска. Частное собрание

О. С. Севериевой 
Если ограничиться только перечислением сюжетов, отраженных в работах Н. А. Северцовой, то можно было бы предположить, что они не многим отличаются от традиционных сюжетов передвижнического толка, столь набивших оскомину еще полвека тому назад и бесчисленно варьируемых в наше время живописцами советской школы. Однако, такой вывод меньше всего отвечал бы истине. Живописные приемы H. А. Северцовой настолько своеобразны, что заставляют выделить ее искусство из общего потока продукции советских живописцев, как явление совершенно оригинальное и современное в самом творческом понимании этого слова. Постараемся разобраться, в чем же его своеобразие и современность. Начнем с того, что рисовать Н. А. Северцова вообще не умеет. Во всяком случае рисовать «по правилам», соблюдая пропорции, перспективу и т.д. [11, с. 33].

Однако, в ее карандашных набросках, напоминающих рисунки детей, где смещены все пропорции, где кривая перспектива, нас странно поражает то, что перспектива прямая и обратная находятся в каком-то необъяснимом содружестве, а смещенные пропорции не случайны, а служат программности замысла и заострению характеристик, перекликающихся то с русским лубком, то с бытовым жанром И. С. Шмелева, или Л. И. Соломаткина, то с гравюрами О. Домье. И, наряду с этим, в картинах Н. А. Северцовой линиям, как очертанию фигур и предметов, иногда свойственна такая певучесть и изящество, которая вызывает в памяти фрески Фра Беато Анджелико, иранскую миниатюру, русскую икону [3, с. 102].

Материалами Н. А. Северцовой служат картон, фанера, иногда жесть. Она бережно наносит на них кистью красочные слои, лессируя, иногда растирая краску пальцем, чем достигает удивительной мягкости цветовых соотношений. Композиционные построения Н. А. Северцовой разнообразны, но, чаще всего, фронтальны, овальны. 
АРТ-платФОРМА. 2020. Вип. 2

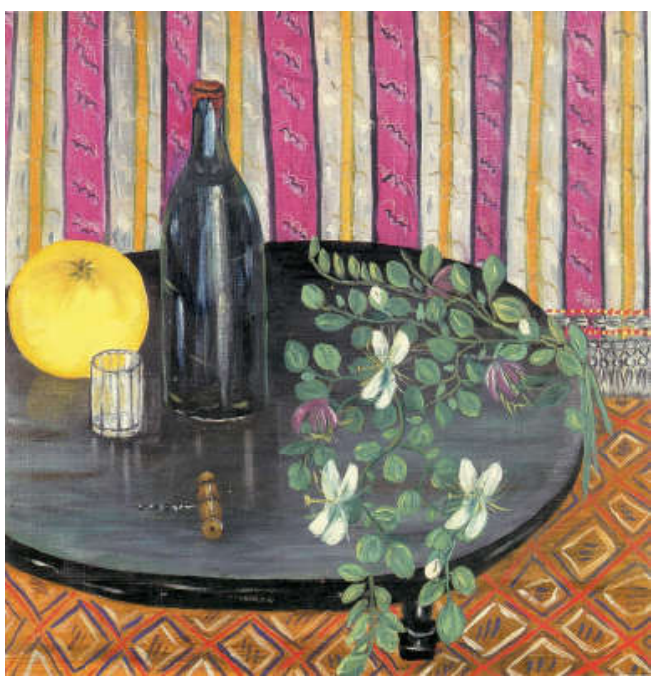

Рис. 4. Севериова Н. А. «Татарский столик с желтой дыней и каперсами». 15(8).08.1951 г. Холст, масло. Частное собрание О. С. Севериевой

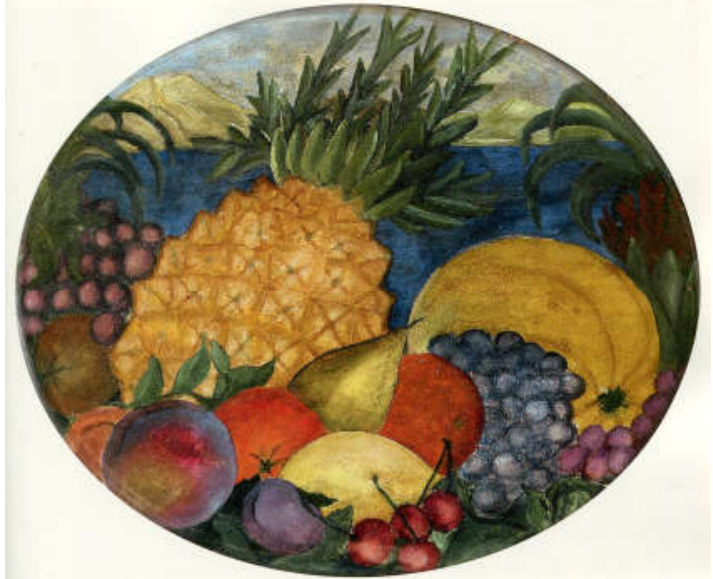

Рис. 5. Н. А. Севериуова. «Фрукты на рассвете (натюрморт с ананасом)». 12.09. 1951 2. Картон, масло. Частное собрание О. С. Севериевой 


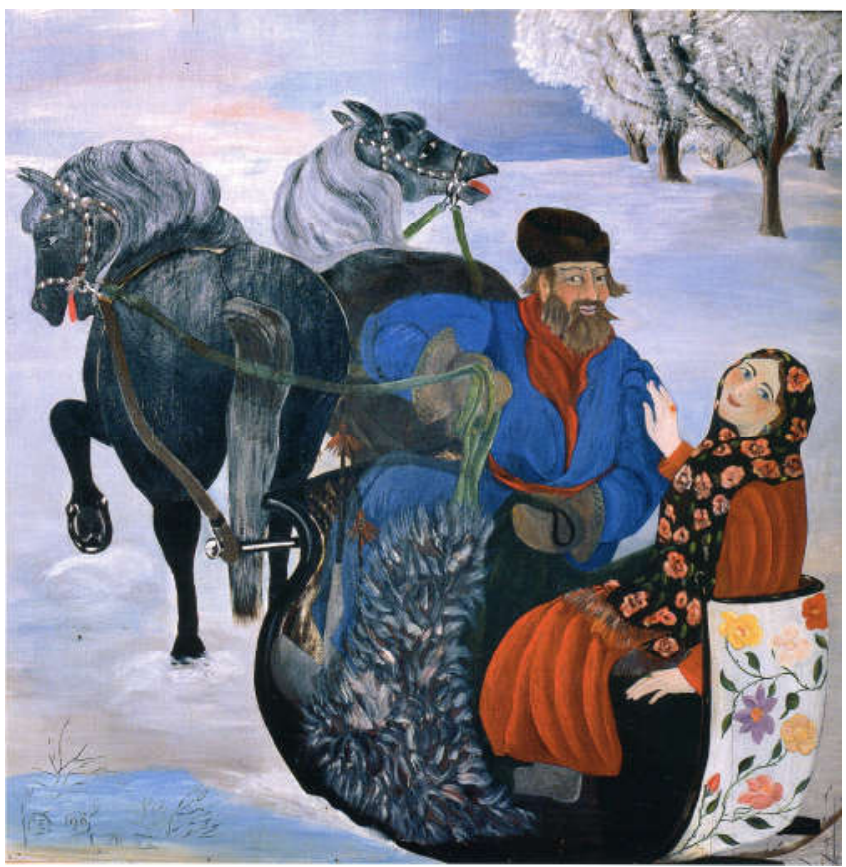

Рис. 6. Севериова Н. А. «Санька в санках (Ямщик)». 1962 г. Фанера, масло. Частное собрание О. С. Севериевой

Иногда эти композиции настолько приближены к зрителю, что первый план словно выходит за пределы нижней границы кадра, как это мы видим в работах «Монахах. Пасха (После заутрени в монастыре)», «Никто никому не грубит. Шалман», «Парикмахерская» [3, с. 32]. Фронтальны и многие из лучших натюрмортов, такие, как «Окорок» или «Кулич», напоминающие по композиции трактирные вывески народных умельцев. Особенно достойны внимания натюрморты мастера. Они полны жизни и декоративны, в них живет уют дома Габричевских. О. С. Северцева вспоминала, что Наталья Северцова, сходив с друзьями живописцами в музей, потом изображала их в лицах персонажей А. Матисса и П. Пикассо. 


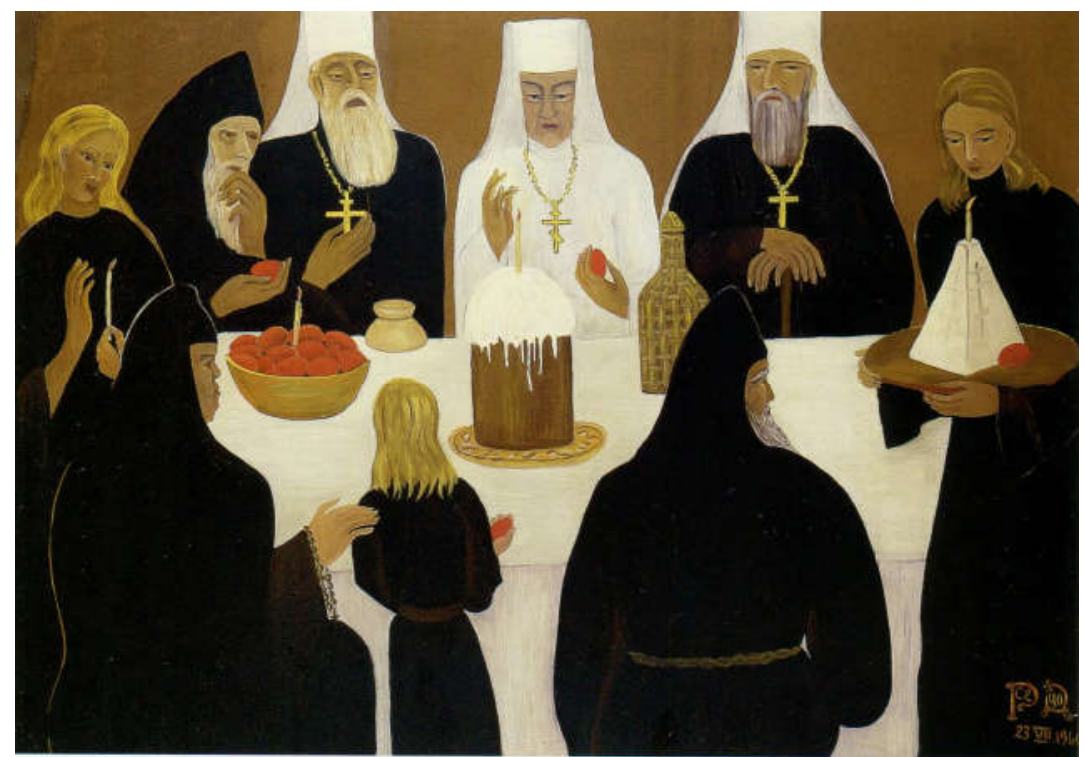

Рис. 7. Севериова Н. А. «Монахи. Пасха (После заутрени в монастыре)». 23.07.1960 г. Оргалит, масло, 119,0 X 164,0 см. Частное собрание О. С. Севериевой

В натюрмортах можно заметить, что она не осталась глуха и к декоративным приемам матиссовских панно. Большая эрудированность, постоянный контроль со стороны, неравнодушно, относившихся к ее творчеству близких придают творчеству художницы многие черты профессионализма, которых на найдешь у наивных художников из народа. Но, все же, наиболее сильной стороной ее искусства является его любительская, домашняя интонация, приближенность к собственному быту, конечно, весьма, неординарному» [12, c. 135]. В больших ее композициях все не так просто. Так, например, в работе «Монахи. Пасха (После заутрени в монастыре)» верхний ряд черных фигур, расположенных овалом вокруг белого стола по традиционной схеме: «Тайных вечерь», 
изображен в фас и прерывается в центре белой фигурой игуменьи.

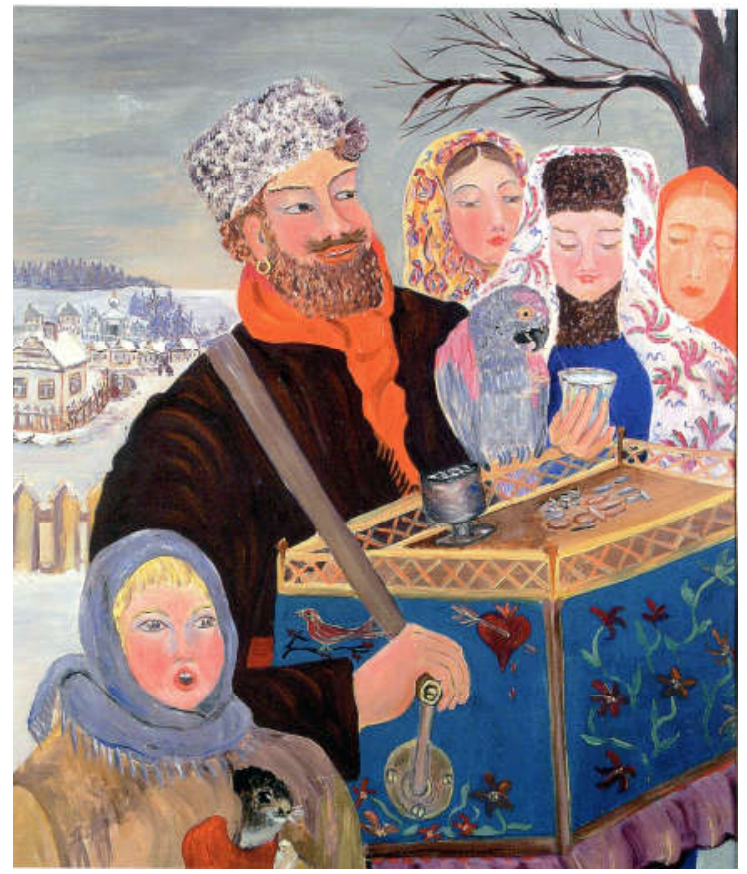

Рис. 8. Севериова Н. А. «Шарманщик». Начало 1960-х годов.

Картон, масло. Коллекция музея Царицыно

Между тем, внутри этого большого овала есть еще малый овал, образуемый киноварью яиц, ритмической цепью замыкающих большое алое пятно корзины с яйцами, несколько сдвинутой в сторону от центра. И этот сдвиг нарушает симметрию композиции, придавая ей характер непосредственной случайности. Принцип фронтальности, своеобразно варьируемый, свойственен и многим другим композициям Н. А. Северцовой, в частности, «Парикмахерской», одной из ее самых зрелых работ, где центральная фигура, написанная в фас, 
является композиционным стержнем, вокруг которого расположено несколько фигур в разных поворотах, а одна даже запрокинута в сложном ракурсе - головой на зрителя.

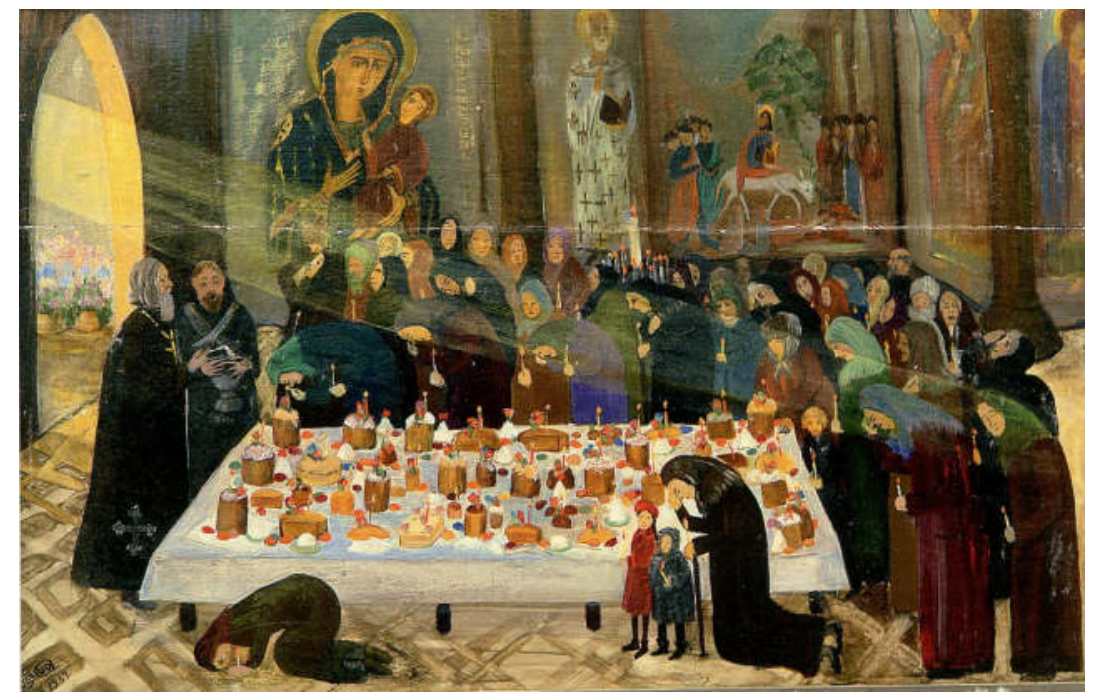

Рис. 9. Севериова. Н. А. «Освещение куличей». 02.08.1964 г. Картон, бумага, масло. Частное собрание О. С. Севериевой

Со всей откровенностью ничем не маскируемый принцип фронтальности выявлен в парных портретах, таких как «Жених и невеста», или «Фрайер и бандерша», а также в портретах индивидуальных, как «Бага», или «Девушка с блюдом рыб», перекликающихся с иранской миниатюрой и итальянским Кватроченто. Интересно проследить в этой связи те нити, которые соединяют искусство Н. А. Северцовой с живописными традициями. Это и русский народный лубок («Жених и невеста»), и русские лаки («Санька в санках. Ямщик»), и трактирные вывески (ряд натюрмортов), и икона («Георгий Победоносец», «Девушка с блюдом рыб»). Это и голландские жанристы XVII в. («Базарный цикл»), и восточная фреска 
(«Татары за трапезой»), и французская карикатура XIX в., перенесенная на русскую почву («Никто никому не грубит. Шалман», «Парикмахерская»). Это и цветовая изысканность мастеров парижской школы. В колоритае живописи преобладают чистые, яркие тона.

Особенно прекрасны они в «Татарах за трапезой», где зеленый, розовый, коричневый и фиолетовый цвета создают аккорд редкого звучания и интенсивности [3, с. 48]. В совершенно другом ключе созданы «Монахи. Пасха (После заутрени в монастыре)», где аскетическая строгость белых и черных оттенков подчеркнута темной охрой фона [3, с. 48]. Иное цветовое решение «Парикмахерской» с ее гаммой белесовато-серых, голубовато-зеленых тонов, нарушенных ярко-розовым фортиссимо центральной фигуры [3, с. 48]. И совершенно по-иному написан «Никто никому не грубит. Шалман» с его изысканной гаммой и приглушенностью цвета, лишь в нескольких местах нарушаемой грязно-розовыми майками пьяниц и красными пятнами раков [3, с. 48]. Колорит картин Н. А. Северцовой продуман не только в целом у каждой из них, но и в отношении отдельных кусков благодаря тому, что цвета соседствуют друг с другом в самых изысканных сочетаниях, особенно ощутимых при анализе деталей. Цвет является у $\mathrm{H}$. А. Северцовой не только значительным компонентом живописи, но и подчеркивает замысел, идею картины. Чтобы убедиться в этом, достаточно сравнить работы «Монахи. Пасха (После заутрени в монастыре)» и «Никто никому не грубит. Шалманом», «Санька в санках. Ямщик» с произведением «Татары за трапезой» [3, с. 45]. Цвет делает картины Н. А. Северцовой то радостными и праздничными, как шум ярмарки, то строгими, как ритуальный обряд. Он находится в тесном соотношении с композицией, фактурой, ритмом и сюжетом картины.

Наряду с этим, искусству Натальи Северцовой свойственна чистота души, нарушить которую ничто не 
угрожает, настолько она органична с природой, радостным, праздничным и оптимистическим восприятием жизни художницы. Любование людьми и природой, животными, цветами и плодами, весенними овощами и осенней листвой толкает ее на то, чтобы взять в руки кисть. Люди, смотрящие на нас с ее картин, добры и красивы. Но ее доброму восприятию мира сопутствует юмор.

И тогда она весело шутит, подтрунивает, иронизирует, а иногда и разоблачает своих любимцев, создавая шаржированные портреты, олицетворяющие человеческие слабости, тупость и невежество. Однако, и тогда ее искусство не покидает праздничное самочувствие и любовь к жизни, полной контрастов и противоречий, и все же прекрасной. В живописи Н. А. Северцова выражает свое восприятие мира, выражает себя со всей своей неповторимой индивидуальностью.

Искусство Н. А. Северцовой реалистично и народно. Деформируя действительность, она искренне предана ей. Это отражено и в ее сюжетах, и в доходчивости живописных приемов, иногда достигающих иллюзорного сходства с натурой.

Ее искусство глубоко национально: оно неразрывно связано с русскими праздниками, русскими людьми, русской природой, русскими традициями. И оно остается глубоко русским, несмотря на все западные и восточные влияния, вряд ли даже осознанные художником. Но, может быть, именно благодаря им оригинальная и самобытная живопись Наталии Северцовой становится в один ряд с подлинно современными явлениями мирового искусства.

Отдельно акцентируем, ценил ли сам А. Г. Габричевский живописный талант своей жены. По мнению русского художника Р. Р. Фалька, который преподал ей несколько уроков, А. Г. Габричевский недостаточно ценит талант своей жены. Фальк считал, что ему мешает академическое воспитание. И, хотя А. Г. Габричевский был широчайше образованным историком и тонким ценителем искусства, но, как многие 
«обыкновенные» хорошие профессиональные художники, считал, что картины Натальи Алексеевны - самодеятельность, или стилизация лубка [3, с. 37]. На самом же деле, у нее собственное, индивидуальное мироощущение. Ее персонажи, будто прямо из жизни «выхваченные» художницей, глубоко реальны, но отнюдь не натуралистичны.

Первая большая выставка работ Н. Северцовой прошла еще при ее жизни, в Институте теории и истории архитектуры, в 1968 г. Это стало событием в культурной жизни Москвы тех лет. Самый факт показа произведений, созданных свободно, без правил и заданий, уже был интересен, важен. Обаяние произведений Н. А. Северцовой многие запомнили тогда навсегда. После ее смерти в 1970 г. О. С. Северцева организовала серию выставок живописи, скульптуры и коллажей Н. А. Северцовой, в т. ч. выставки в Музее Царицыно и в музее-квартире С. Т. Рихтера, с которым Наталья Северцова и Александр Габричевский были очень дружны. Уникальным достижением деятельности О. С. Северцевой также явилась выставка из серии «Искусство в кругу ученых. Собрание Станкевичей-Габричевских-Северцовых», посвященная 250-летию Московского государственного университета (проводилась в ГМИИ им А. С. Пушкина с 3 февраля по 6 марта 2005 г.) [7]. Помимо организации выставок, О. С. Северцева издала книгу к столетию со дня рождения А. Г. Габричевского, посвященную его жизни, науке и искусству, его друзьям и выдающимся людям этого круга, а также двухтомный сборник документов и воспоминаний из архивов ГабричевскогоСеверцовой $[6 ; 8 ; 10]$.

Выводы. Н. А. Северцова всегда стремилась к творчеству, делала игрушки, фигурки из корней, пробовала себя как актриса. Но нашла свое призвание лишь к пятидесяти годам, когда после инфаркта начала рисовать. Ее самобытные работы, сохраненные потомками и друзьям, поражают любовью к людям, восхищением и упоением жизнью. В произведениях 
Н. А. Северцовой мы имеем пример русского искусства, выросшего на базе общеевропейской культуры начала XX в. и самостоятельно развивавшегося в духе свободы новых художественных открытий 1950-1960-х гг.

\section{Литература}

1. Балдина О. Второе призвание. Москва: Молодая гвардия, 1983. 124 с.: ил.

2. Волкова П. Мы заждались вас, Наталья Алексеевна. ДИ. 2007. №6. С. 132-134.

3. Галерея Полины Лобачевской: Наталья Северцова (19011970). Живопись из собрания Ольги Северцовой и Федора Погодина-Стукалова. Сост. Е. Плавинская. Москва: Государственный центральный музей современной истории России, 2007. 129 с.

4. Жарков Е. Страна Коктебель. Культурные очаги. Середина XIX - середина XX веков. Киев: Болеро, 2008. 608 с.: ил.

5. Из воспоминаний Н. А. Северцовой-Габричевской. Старый добрый Коктебель: природа, история, филология, мифология, люди. Т. М. Фадеева, А. К. Шапошников. Симферополь: Бизнес-информ, 2008. С. 262-293.

6. Из записок Н. А. Северцовой. 1968 г. Александр Георгиевич Габричевский: биография и культура: документы, письма, воспоминания: [в 2 книгах. Сост., археограф. работа, коммент. О. С. Северцева]. Москва: РОССПЭН, 2011. С. 96-99.

7. Искусство в кругу учёных: собрание СтанкевичейГабричевских-Северцовых: живопись, графика, скульптура, архивные документы из музеев Москвы и частного собрания. Москва: [б. и.], 2005.9 с.: ил.

8. Климов Р. Живопись Натальи Северцовой. Александр Георгиевич Габричевский, 1891-1968: К 100-летию со дня рождения. Москва: Советский художник, 1992. С. 59-70. 
9. Климов Р. Теория стадиального развития искусства и статьи. Москва: О.Г.И, 2002. 498 с.: ил.

10. Роман в письмах (1942-1944). Александр Георгиевич Габричевский: биография и культура: документы, письма, воспоминания: [в 2 книгах / сост., археограф. работа, коммент. О.С. Северцева]. Москва: РОССПЭН, 2011. С. 333-565.

11. Румнев А. Наталия Северцова - живописец // РГАЛИ. Ф. 2721. Оп. 2. Ед. хр. 5. Л. 28-35.

12. Северцова-Габричевская Наталья Алексеевна SeverzovaGabricgedskaya (1901-1970). Богемская К. Г. Наивные художники России $=$ Russian naive and outsider artists: лексикон коллекционера. Санкт-Петербург: Алетейя, 2009. С. 124, с. 133135 , c. 149.

13. Хан-Магомедова В. Про жизнь в Коктебеле. Искусство. 2008. №7. C. 2.

14. Шкаровская Н. Народное самодеятельное искусство. Ленинград: Аврора, 1975. 54 с.: цв. ил.

\section{Ольга Миколаївна Філіппова,}

завідувач архівом, Політехничний музей,

Москва, Росія,

e-mail: iscusstvo0891@mail.ru,

ORCID: 0000-0002-8933-1214

\section{ТВОРЧІСТЬ НАТАЛІЇ СЕВЕРЦОВОЇ}

Анотація. Наталія Олексіївна Северцова-Габричевська (1901-1970 рр.) була яскравою і непересічною особистістю. Природний темперамент, артистичність, краса пригортали до неї вчених і художників. I якщо в московському житті професійна зайнятість і наукові штудії кола друзів ііі чоловіка визначали i ритм, і стиль спілкування, то в Коктебелі, куди їхали жити вільно, грати, відпочивати, складалася атмосфера, в якій розквітав іiі талант господині будинку, душевного кола, дар 
художниці. Н. О. Северцова створювала те, що фахівці визначають як наївне мистецтво. Можна було б сказати, що іiі творчість сформувалася всупереч тим смакам i художнім ідеалам, які були притаманні iї друзям i наставникам 3 найближчого оточення. Це був приклад наївного бачення, що залишається цілим в елітарному середовищі. Проте, Н. О. Северцова була людиною свого кола - справжнім інтелігентом, з властивим незалежно мислячим людям поглядом на світ, гострим, часто іронічним, завжди нестандартним. 3 плином часу - десятків років, що минули з того періоду, коли навколо столу в коктебельському будинку Габричевських збиралася весела дружня компанія, - стає зрозуміло, що гнітючому тиску радянської дійсності протистояли люди, пов'язані дружніми і професійними стосунками, спільними інтересами і захопленнями. У мистецтві Н. Северцової втілився той спосіб життя і стиль самовираження, який був притаманний колу людей, що збиралися в будинку Северцових-Габричевских, успадкували побутову культуру батьків і дідів, зберігали їх звички, манери, способи судження настільки ж дбайливо, як твори живопису і графіки, що діставалися у спадок. Ці традиції продовжує зберігати племінниця і вихованка Н. О. Северцової О. С. Северцева (н. 1931 р.). Вона зберегла не тільки всю художню спадщину Н.А. Северцовой, а й архіви всіх вчених, що належали цій винятковій родині.

Ключові слова: творчість Наталії Северцової, Коктебель, мистецтво, музика, театральна студія, актриса, звуконаслідувач, живопис, натюрморти, портрети 


\title{
Olga N. Filippova, \\ Head of the Department of the Polytechnic Museum, \\ Moscow, Russia, e-mail: iscusstvo0891@mail.ru, \\ ORCID: 0000-0002-8933-1214
}

\section{CREATIVE WORK OF NATALIA SEVERTSOV}

\begin{abstract}
Natalia Severtsov-Gabrichevsky (1901-1970) was
\end{abstract} a bright and extraordinary personality. Her natural temperament, artistry, and beauty attracted scientists and artists to her. And, if in Moscow life professional employment and scientific studies of her husband's circle of friends determined both the rhythm and style of communication, then in Koktebel, where they went to live freely, play, relax, there was an atmosphere in which her talent as a hostess, a spiritual circle, as well as the gift of an artist flourished. N. A. Severtsova created what experts define as naive art. It could be said that her work was formed contrary to the tastes and artistic ideals that were inherent in her friends and mentors from the inner circle. This was an example of a naive vision remaining intact in an elite environment. However, N. A. Severtsova was a person of her own circle - a true intellectual, with an inherent, independent, thinking people's view of the world, sharp, often ironic, always nonstandard. With the passage of time - tens of years since the time when a cheerful friendly company gathered around the table in the Koktebel house of the Gabrichevskys - it becomes clear that the oppressive pressure of Soviet reality was resisted by people connected by friendly and professional relations, common interests and hobbies. N. A. Severtsova's art embodies that way of life and style of self-expression, which was inherent in the circle of people gathered in the house Sewerzowii-Gabrichevski, which inherits the consumer culture of our fathers and grandfathers kept their habits, manners, ways of judgment as carefully as paintings and graphics, get a legacy. These traditions continue to be kept by niece and pupil 
of N. A. Severtsova - O. S. Severtsev (b. 1931). It has preserved not only the entire artistic heritage of N. A. Severtsova, but also the archives of all scientists who belonged to this exceptional family.

Key words: the creative work of Natalia Severtsova, Koktebel, art, music, theater studio, actress, onomatopoeic, painting, still-lifes, portraits

\section{References}

1. Baldina, O. (1983). Vtoroe prizvanie [The second call], Moscow: Molodaja gvardija [in Russian].

2. Volkova, P. (2007). My zazhdalis' vas, Natal'ja Alekseevna [We've been waiting for you, Natalia Alekseevna]. In: DI, 6,132-134 [in Russian].

3. Galereja Poliny Lobachevskoj: Natal'ja Severtsova (19011970) (2007). Zhivopis' iz sobranija Ol'gi Severtsovoj i Fedora Pogodina-Stukalova. Sost. E. Plavinskaja [Polina Lobachevskaya Gallery: Natalia Severtsova (1901-1970). Paintings from the collection of Olga Severtsova and Fedor Pogodin-Stukalov]. Moscow: Gosudarstvennyj tsentral'nyj muzej sovremennoj istorii Rossii [in Russian].

4. Zharkov, E. (2008). Strana Koktebel'. Kul'turnye ochagi. Seredina XIX - seredina XX vekov [Koktebel Country. Cultural center. Mid of the XIX - mid of the XX centuries], Kiev: Bolero [in Russian].

5. Iz vospominanij N. A. Severtsovoj-Gabrichevskoj. Staryj dobryj Koktebel': priroda, istorija, filologija, mifologija, ljudi (2008). T. M. Fadeeva, A.K. Shaposhnikov [From the memoirs of N. A. Severtsov-Gabrichevskii. Good old Koktebel: nature, history, philology, mythology, people. T. M. Fadeeva, A. K. Shaposhnikov]. Simferopol: Biznes-inform [in Russian].

6. Iz zapisok N. A. Severtsovoj. 1968 g. (2011). Aleksandr Georgievich Gabrichevskij: biografija i kul'tura: dokumenty, pis'ma, vospominanija: v 2 knigah. Sost., arheograf. rabota, komment. O. S. Severtseva. [From the notes of N.A. Severtsova]. Alexander 
Georgievich Gabrichevsky: biography and culture: documents, letters, memories. Moscow: ROSSPEN, 96-99 [in Russian].

7. Iskusstvo $\mathrm{v}$ krugu uchjonyh: sobranie StankevichejGabrichevskih-Severtsovyh: zhivopis', grafika, skul'ptura, arhivnye dokumenty iz muzeev Moskvy i chastnogo sobranija (2005). [Art in the circle of scientists: the Stankevich-Gabrichevsky-Severtsov collection: paintings, drawings, sculptures, archival documents from Moscow museums and private collections]. Moscow: [b. i.] [in Russian].

8. Klimov, R. (1992). Zhivopis' Natal'i Severtsovoj. Aleksandr Georgievich Gabrichevskij, 1891-1968: K 100-letiju so dnja rozhdenija [Painting of Natalia Severtsova.Alexander Georgievich Gabrichevsky, 1891-1968: To the 100-th anniversary of his birth], Moscow: Sovetskij hudozhnik, 59-70 [in Russian]

9. Klimov, R. (2002). Teorija stadial'nogo razvitija iskusstva i stat'i [The theory of the stadial development of art and articles], Moscow: O.G.I [in Russian].

10. Roman V pis'mah (1942-1944). (2011). Aleksandr Georgievich Gabrichevskij: biografija i kul'tura: dokumenty, pis'ma, vospominanija: v 2 knigah / sost., arheograf. rabota, komment. O. S. Severtseva [Roman in letters (1942-1944). Alexander Georgievich Gabrichevsky: biography and culture: documents, letters, memories]. Moscow: ROSSPEN, 333-565 [in Russian].

11. Rumnev, A. Natalija Severtsova - zhivopisets [Natalia Severtsova-painter]. RGALI. F. 2721. Op. 2. Ed. hr. 5. L. 28-35 [in Russian].

12. Severtsova-Gabrichevskaja Natal'ja Alekseevna SeverzovaGabricgedskaya (1901-1970) (2009). Bogemskaja K. G. Naivnye hudozhniki Rossii = Russian naive and outsider artists: leksikon kollektsionera [Severtsova-Gabrichevskaya Natalia Alekseevna Severzova-Gabricgedskaya (1901-1970). Bogemskaya K. G. Naive artists of Russia $=$ Russian naive and outsider artists: collector's lexicon], Saint-Petersburg: Aletejja, 124, 133-135, 19 [in Russian]. 
13. Han-Magomedova, V. (2008). Pro zhizn' v Koktebele [About life in Koktebel]. Iskusstvo, 7, 2 [in Russian].

14. Shkarovskaja, N. (1975), Narodnoe samodejatel'noe iskusstvo [Folk Amateur art]. Leningrad: Avrora [in Russian]. 